\title{
XIII Coloquio Internacional de Hermenéutica Analógica
}

Los días 3, 4 y 5 de octubre de 2017 se celebró el XIII Coloquio Internacional de Hermenéutica Analógica, en la sala José Gaos del Instituto de Investigaciones Filosóficas de la UNAM. En esta ocasión contamos con investigadores, profesores y estudiantes tanto de licenciatura como de posgrado que compartieron trabajos de distintas disciplinas, como la ética, la estética, la literatura y el derecho, entre otras, en torno a la hermenéutica y a la propuesta del doctor Mauricio Beuchot, la hermenéutica analógica.

Asimismo contamos con la participación del doctor Rafael Cúnsulo, quien inauguró el Coloquio con la conferencia "Metáforas y símbolos en la filosofía de la religión", en la que, con base en la propuesta beuchotiana, analizó y resaltó la importancia de Dios como símbolo e icono en el ser humano, a manera de metáfora, esto es, la comprensión religiosa (como experiencia) contenida metafóricamente hacia la imagen de Dios en el ser humano.

Los temas que más destacaron en el coloquio fueron en torno a la persona, la justicia y la solidaridad, así como el llamado "nuevo realismo", que es parte del nuevo giro ontológico, que está desbancando lo que desde mediados del siglo xx se denominó "giro lingüístico". Hablando del nuevo realismo, esta ocasión tuvimos la presencia de Mauricio Beuchot, quien dictó la conferencia de clausura intitulada "Mirando hacia el futuro: el realismo analógico", donde destacó que el realismo y el idealismo se deben corresponder analógicamente por medio del juicio, de tal manera que ponga en crisis la realidad. No todo lo que se halla en la realidad es tal y como es dado; es más, ni siquiera debería pensarse la realidad como dada, pues estaríamos cayendo en un univocismo radical 
como el del positivismo lógico. Tampoco debemos pensar en la realidad únicamente como mera construcción del sujeto, pues estaríamos cayendo en un equivocismo con una posible desembocadura hacia el relativismo extremo, donde toda la realidad es creada por el aparato psíquico del sujeto. Beuchot enfatizó la correspondencia proporcional que pudiera haber entre el pensar la realidad y el vivirla. De este modo podría abrirse la posibilidad de un realismo analógico, inmerso en el nuevo realismo y, a su vez, en el giro ontológico.

Pero esto no fue todo. En el marco del Coloquio, el 6 de octubre contamos con la presencia de tres distinguidos profesores de la Facultad de Filosofía y Letras: los doctores Pedro Enrique García, Jorge Armando Reyes y Carlos Oliva, quienes impartieron la charla "Perspectivas hermenéuticas". En ésta, los profesores dieron su postura sobre la hermenéutica y trataron de corresponderse entre sí a través de la hermenéutica analógica. Surgieron temas como la traducción intersubjetiva, la interpretación ontológica del otro y el surgimiento de la cultura por medio del quehacer espiritual del hombre, esto es, como la comprensión reflexiva de sí y del otro.

Sin duda ha sido una de las mejores ediciones del Coloquio Internacional de Hermenéutica Analógica, pues cada vez se percibe más interés en la propuesta de Beuchot y surgen más generaciones de posibles hermeneutas analógicos.

Aldo CAmacho

Claudia González 